Authors' Copy as Accepted for Publication

Maria Kaparou (1) and Tony Bush (2)

(1) School of Education, The University of Nottingham Malaysia Campus, Malaysia

(2)School of Education, The University of Nottingham (Malaysia and UK), Nottingham UK

\title{
Instructional Leadership in Centralised Systems: Evidence from Greek High Performing Secondary Schools
}

\begin{abstract}
This paper examines the enactment of instructional leadership in high-performing secondary schools (HPSS), and the relationship between leadership and learning in raising student outcomes and encouraging teachers' professional learning in the highly centralised context of Greece. It reports part of a comparative research study focused on whether, and to what extent, instructional leadership has been embraced by Greek school leaders. The study is exploratory, using a qualitative multiple case design to examine two HPSS in Athens. The research design involved a qualitative approach using several different methods, including semi-structured interviews with school principals, deputy heads, subject teachers and subject advisers, plus observation of leadership practice and meetings and scrutiny of relevant policy documents. The findings show that instructional leadership is conceptualised as an informal collaborative leadership practice, interwoven with the official multidimension role of Greek principals and their 'semi-instructional leadership' role. In the absence of official instructional leadership 'actors', teachers' leadership has been expanding.
\end{abstract}

\section{Keywords}

instructional leadership, leadership for learning, high-performing secondary schools, school improvement, centralised systems, Greece 


\section{Introduction}

The purpose of this paper is to explore the application of instructional leadership in the highly centralised context of Greece. The current literature on this topic is dominated by research in partly decentralized contexts, where principals and other leaders have significant scope to lead and manage teaching and learning (e.g., Hallinger and Murphy, 1985 for the U.S.A.; Southworth, 2002 for England; Marks and Printy, 2003 for the U.S.A.; Sahlberg, 2007 for Finland). The research on which this paper is based examined whether, and to what extent, principals are able to exert influence over the curriculum, notably in interpreting and implementing national policy.

There is a growing recognition that teaching quality and school leadership are the two key influences on student learning (Leithwood et al., 2008; Robinson et al., 2008; Swaffield and MacBeath, 2009; Bush et al., 2010; Hallinger and Heck, 2011). The European Union (EU) is one important organisation to stress the importance of teaching and leadership quality:

The knowledge, skills and commitment of teachers, as well as the quality of school leadership, are the most important factors in achieving high quality educational outcomes... It is essential ... to ensure that those recruited to teaching and school leadership posts are of the highest calibre and well-suited to the tasks they have to fulfil. (European Union, 2009)

Research and literature in different international contexts shows how classroom practice and leadership impact on student learning (e.g. Day et al., 2007; Leithwood and Jantzi, 2008; Robinson et al., 2008; Bush and Glover, 2009; Dempster and Bagakis, 2009). An instructional leadership focus is an important pathway for teachers' professional improvement and student learning. The origins of instructional leadership lie in research on elementary schools in the USA (e.g. Bossert et al., 1982; 
Hallinger and Murphy, 1985). Subsequently, the increasing emphasis on the improvement of teaching and learning led to increasing interest in principal instructional leadership in some European countries (e.g., Day et al. 2001; Southworth, 2002; LISA, 2009).

While the empirical knowledge base in instructional leadership in Europe began at the turn of the millennium, an emerging interest in centralised contexts across the world, including Botswana (Pansiri, 2008), Lebanon (Mattar, 2012), Thailand (Hallinger and Lee, 2014), and Turkey (Gumus and Akcaoglu, 2013), was identified. However, the practice of instructional leadership (IL) has been barely considered in Greece. There has been very little discussion about how leadership is conceptualized, on how student outcomes are improved, and whether and how leadership impacts on school improvement (e.g. Demertzi et al., 2009). This paper presents important new evidence in the highly centralised context of Greece, where the formal expectations are for principals to act as administrative, rather than, instructional leaders.

Similar to the centralised French education system (Normand, 2014), the main characteristics of the educational system in Greece are its hierarchical structure which gives limited autonomy and authority for principals to intervene in instructional aspects of schooling- and top-down decision-making (see Saiti, 2000; Saitis, 2002; Athanasoula-Reppa and Lazaridou, 2008).

Within this contextual framework, the paper seeks to answer the following research questions in respect of high performing secondary schools:

1) Whether, and to what extent, Greek principals are instructional leaders?

2) If so, how do they act as instructional leaders? 
The study examines whether, and to what extent, Greek principals enact instructional leadership (IL), while it also explores the key dimensions of instructional leadership practiced in high-performing secondary schools. The first research question investigates whether IL has been embraced by Greek principals as an effective leadership approach, despite the administrative constraints of their role. Understanding principals as instructional leaders requires their leadership actions' translation into a culture conducive to students' learning and teachers' professional development, and this is the main focus of the second research question.

Given that 'the way policy is made is highly contextualised and its implementation even more context-dependent' (Rui, 2007: 241), this research sought to identify similarities and differences between high performing schools in Greece, where leadership practices may be expected to be uniform because of the effects of centralisation.

\section{Literature Review}

Theoretical Background: Perspectives on Instructional Leadership

The American literature predominantly refers to instructional leadership (e.g., Hallinger and Murphy, 1985; Heck et al., 1990; Krug, 1992; Blase and Blase, 2004). Several studies (e.g. Hallinger and Heck, 1997; Day et al., 2007; Bush et al., 2010) stress that instructional leadership is highly concerned with the 'technical core of education', teaching and learning, where the focus is leading teachers' professional learning to improve student outcomes. For example, Southworth (2002: 79) states that 'instructional leadership is strongly concerned with teaching and learning, 
including the professional learning of teachers as well as student growth', incorporating a number of practices that explore the relationship between principal leadership and pupil achievements. Leithwood et al. (1999: 8) suggest that 'instructional leadership [...] typically assumes that the critical focus for attention by leaders is the behaviour of teachers as they engage in activities directly affecting the growth of students.' All these definitions highlight the indirect effect of principal leadership on student achievement through professional collaboration and learning.

While instructional leadership is widely advocated, there are also several criticisms of this approach, regarding its conceptual and practical limitations (Hallinger, 2010), which have led to the alternative concept of leadership for learning. This concept provides 'a wider perspective of who might exercise instructional leadership' (Bush, 2014: 3).

In contrast to earlier accounts, which emphasized a solo model of instructional leadership, recent models have recognized the need for shared instructional leadership practices (e.g. Marks and Printy, 2003). Similarly, evidence from outstanding schools in England (e.g., Ofsted, 2009; Macfarlane and Woods, 2011) illustrates the significance of learning-centred leadership practices, with a sense of shared ownership for the improvement and growth of the schools. The trend towards a more shared sense of instructional leadership supersedes the top-down (principal) instructional leadership model of the 1980s. As Hallinger (2009:1) notes, 'instructional leadership has recently reincarnated as a global phenomenon in the form of "leadership for learning", which is conceived as a more distributed and/or shared school leadership paradigm for $21^{\text {st }}$ century school contexts. MacBeath and 
Dempster (2009) argue that there is no firm definition of 'leadership for learning' as its usage is influenced by the organizational context.

Despite the debate regarding the 'conceptual elasticity' (MacBeath and Townsend, 2011: 5) of this concept, related to the focus on 'instruction [which] predisposes people to think in terms of teaching rather than learning [...]' (MacBeath, 2006: 39), the researchers decided to keep 'instructional leadership' as a working term, since it is the most widely used descriptor.

Learning is the central focus of school leadership in high-performing schools (e.g. Murphy et al., 2007) and this justifies why instructional leadership is thought to be of central importance in schools that have been recognized as outstanding. The contribution of leadership to school improvement is widely acknowledged and the literature shows that high quality academic and/or professional learning requires an instructional leadership orientation (e.g. Leithwood et al., 2006).

\section{Instructional leadership in centralised systems}

Centralisation within educational systems reinforces an administrative style of leadership, indicating little capacity to improve teaching and learning processes (e.g., OECD, 2009). However, a different picture is painted within the centralised Cypriot educational system. As part of the International Successful School Principalship Project (ISSPP), Pashiardis and Savvides (2011) show how the instructional and entrepreneurial aspects of leadership interact to build the capacity for student learning, while principals focused on improving student achievement and employed a learningcentred leadership approach to assist students' academic performance. Mattar's (2012: 
523) survey in Lebanese schools also shows that "principals in the high-performing schools were adopting a stronger instructional leadership style than those in the lowperforming schools'.

However, Gumus and Akcaoglu's (2013) survey of Turkish primary school principals showed that they only occasionally practised instructional leadership to improve student achievement. This is the outcome of a bureaucratic system in which expectations remain at an administrative level, 'leaving the instructional duties to teachers without providing the support and guidance teachers need.' (ibid: 290) In contrast, Lai and Cheung's (2013) study of principals' instructional leadership practices in Hong Kong which is shifting from a centralised model to a greater degree of autonomy, shows that a shared dimension of building vision and direction setting was adopted by principals in successful schools. Although the centrally developed school curriculum in Hong Kong is likely to suggest that principals are 'passive implementing agents' (ibid: 336), there is interactive engagement to adjust the external curriculum to the school's curriculum goals.

Hallinger and Lee's (2014) study of Thailand confirms the difficulty of changing the principal's role orientation from a managerial to an instructional leadership profile within a highly centralised system that gives principals little space for initiating policy. However, they add that secondary school principals' engagement with instructional leadership is significantly stronger than principals at a primary level.

\section{Instructional leadership in Greece}


Educational leadership has not been widely explored in the Greek context. Centralization, bureaucratic complexities, an administrative oriented role, and topdown decision making, do not leave enough space for school-level innovation. Bagakis (2007a: 162) states that:

in schools there are some routines that are difficult to change. In schools, discussions about classroom practices are not taking place at all, or there are a few. ... the beggarly salaries, the bad law in education, the bad curriculum, the bad textbooks, ... the bad training, the bad educational reforms are usually discussed.

Much of the Greek literature is what Muijs (2011:116) has called 'position papers', which are not based on empirical research or systematic literature reviews, but look overseas to offer statements about the best way to manage a school. This raises the question of whether Greek scholars conceive school administration as a status quo that cannot be exercised differently within Greece. Most studies of school leadership (Papanaoum, 1995; Saitis et al., 1997; Saitis and Menon, 2004; Christodoulou, 2007; Athanasoula- Reppa and Lazaridou, 2008) highlight the notion of 'headteacheradministration processor', with principals having very limited powers to address the need for major school adjustments or reforms. This appears to confirm Bagakis's (2007b: 270) point that 'educational leadership is in its infancy'. Gkolia and Brundrett (2008: 48) also note 'the comparative absence of studies on the effectiveness of Greek schools'.

Evidence from 'The Carpe Vitam Leadership for Learning Project' adds significantly to the empirical knowledge base about school leadership in Greece. Demertzi et al. (2009: 303) note that, 'given the structure of the Greek education system, we found no evidence of the distribution of leadership through an established system or the attribution of shared roles.' MacBeath (2006: 43) perceptively states that: 
[i]n Greek schools, principals spoke of constantly bumping up against a tradition that attached specific and inflexible roles to the head teacher, teachers, parents, and the school custodian.

Biniari's (2012) doctoral study in one low-secondary school in Athens confirms that norms of professional collaboration have not been formalised in Greek state schools, 'possibly due to the lack of the appropriate organisational climate.' (ibid: 214) However, Demertzi et al. (2009: 305) report that one of the principals agreed that initiatives by a group of teachers had established a new culture in the school, a culture that 'challenges traditional standards', experimenting with 'cooperative models of learning and leadership'. MacBeath and Swaffield (2008: 8) argue that the strategy for creating conditions favourable to learning in Athens was:

to use the nucleus of teachers involved in the project as champions of change, through their focus on their own learning and that of their students, through the formal structures of weekly meetings, in the process promoting a cultural shift, a new discourse about learning and teaching and broader distribution of leadership.

Saliaris's (2009: 91-92) quantitative study in two Greek islands showed principals' willingness to 'make some steps' towards a more pedagogical role but, due to the constraints of the centralized educational system, principals could not enact such a role. This suggests that leadership for learning in Greek schools may be activated or constrained by the context.

\section{Methodology}

This research incorporates a qualitative, inductive approach with an emphasis on seeking stakeholders' interpretations of the nature of IL in their high performing contexts. Qualitative research, seeking to investigate how and why a social experience is created, is selected as the most appropriate research approach for 
meeting the purpose of this study, because of its exploratory nature, which has a datatheory (interpretive) stance. This approach led to the choice of case studies as the preferred research approach. This is in line with Yin's (2009: 4) argument that 'the case study method allows investigators to retain the holistic and meaningful characteristics of real-life events- such as [...] small group behaviour, organizational and managerial processes'.

Each of the two researched schools was the subject of an individual case study, while the use of methodological and respondent triangulation in individual case studies created a platform for ensuring reliability and validity through comparing the outcomes from each method (Silverman, 2005; Bush, 2007; Bryman, 2008). This study included two schools and uses a multiple case design. It is important to acknowledge Crossley and Vulliamy's (1984: 204) point that case studies should 'not be limited to the micro-level; and [...] need not ignore comparative analysis itself'. Consequently, the technique that applies to the analysis of these multiple cases is cross-case analysis, which examines the commonalities and differences across the cases (Khan and VanWynsberghe, 2008). Although Stake (2006: 39) argues that 'researchers doing cross-case analysis are emphasizing the common relationships across cases', this study also explores differences between the two schools.

The authors decided to opt for a purposive sample, selecting two outstanding secondary schools, in order to explore the similarities and differences between schools with similar characteristics in a centralised context. Treating the two researched high-performing schools as individual case studies has created a platform for presenting the rich data generated from each case. The two Greek schools 
comprised the top two schools from one district in the prefecture of Attiki (Athens) based on the published Pan-hellenic school examination results showing the proportion of students who entered Greek Schools of Higher Education (University and Technological Education Institutions), for two consecutive years.

\section{$\underline{\text { Methods }}$}

A qualitative approach was adopted, using several methods so that '[m]ultiple sources of data [could] help address the issue of construct validity' (Gray, 2005: 129) and maximise the potential for a higher level of results confidence through a multimethod validation (Cohen et al., 2001), as explained below. The selected methods were:

- Documentary analysis

- Semi-structured interviews

- Observations

\section{Documents}

Scrutinising national level policy documents, in addition to subject advisers' generic documents and school documents, provided a platform for understanding the macro context regarding leadership practices and the micro context, respectively. The national level documents included official statistics of the Panhellenic examinations for one district and several educational laws (e.g, 1566/85, 1304/82, 2525/97, Ministerial Decision 105657/2002). Subject advisers' documents was another tool which helped the researchers 'to read between the lines of official discourse' (Fitzgerald, 2007: 278) regarding their pedagogical actions, before proceeding to data triangulation. These documents included Maths and Greek Philologists' diaries, 
activity planning, and a lesson plan for modelling an Ancient Greek lesson for Greek philologists, the Maths subject adviser's guidelines to teachers for student evaluation, and his report on teachers' performance.

The school documents included teachers' committee pedagogical meetings, school A principal's diary of school life, school A principal's action book, and school B principal's report on school organization and management.

An interpretive stance helped the researchers adopt a critical evaluation of the documents, in order to enhance credibility in the content analysis. Hence, documents were not treated as objectively representative of the social context (Cortazzi, 2002; Rui, 2007), bearing in mind that the scrutinized policy documents (e.g., the Greek educational law) show intentions, while internal documents (e.g. Greek teachers' committee pedagogical meetings' minutes; subject adviser's pedagogical documents) may show subjectivity, perhaps for political reasons. This approach evidenced a gap between the internal and policy documents, and school-level practice, since there is an inconsistency between stakeholders' official job responsibilities and their application.

\section{Interviews}

Semi-structured interviews with a stratified sampling of twenty-six stakeholders provided the basis for respondent triangulation (Robson, 2002; Perakyla, 2008). The purposive sample (Cresswell, 2003; Brundrett and Rhodes, 2014) comprised:

eight subject teachers in each school (4 Mathematics/ Physics/ Biology/ Chemistry teachers and 4 Greek Language and Literature teachers (philologists); the two most 
experienced Greek Philologists and Maths teachers; the principal and deputy head in each school and, the Maths and Greek subject advisers responsible for the case study schools.

The principals, the deputy heads, and the subject advisers responsible for the schools - were purposively sampled. The eight subject teachers - four Greek Philologists and four Science teachers- in each school were chosen through stratified sampling, since Greek Language, Mathematics, Physics, Biology and Chemistry are core subjects for pupils in C Grade - final year before entering the university. The two most experienced subject teachers were purposively sampled as the nearest equivalent to subject leaders in the Greek context.

The interview schedules, targeted to different data sets, were derived from the research questions and the literature on instructional leadership. Both research questions are answered through a combination of questions, as they have a more generic nature, which required a 'helicopter view' for a successful answering. The questions were designed:

- to consider the relationship between principal's instructional leadership and school improvement,

- to explore the level of interaction between principal's instructional strategies and its influence on student outcomes,

- to examine the relationship between instructional leadership and teachers' performance, and,

- to examine the mechanisms for implementing instructional leadership within high performing schools. 


\section{Observations}

Semi-structured observations took place through shadowing the school principals to record the nature and frequency of their IL activities and observing meetings. Conducting a series of observations in each school required the development of a Matrix observation framework (see Appendix 1: Extract of Principal Observation Schedule), guided by a central question:

- What proportion of his/ her time does the principal devote as instructional leader as opposed to management focused activities?

This helped the researchers answer the first research question, 'Whether, and to what extent, Greek principals are instructional leaders?'. In order to find out more about 'How principals act as instructional leaders' (RQ2), the researchers, as nonparticipant observers, took field notes on the behaviour, attitudes and leadership activities (e.g., related to curriculum and teaching Tasks, evaluation of student progress, monitoring, mentoring, modelling, professional development) during observations. As Coldren and Spillane (2007: 372) state, 'to completely understand instructional leadership as a practice, we need to understand how leaders do what they do as well as the role of context in shaping what they do.' In addition, observing school teachers' association pedagogic meetings gave a snapshot of reality within schools. 'Such meetings are regarded as significant for studies of leadership and management issues' (Bush, 2007: 95).

\section{Data analysis}

Thematic analysis grounded the research process within an interpretivist paradigm, in which the interplays between policy, educational actors and IL practices are analysed 
within and across the cases. Boyatzis (1998) identifies thematic analysis as a tool used across different methods in order to identify, analyse, report patterns and interpret the research data, while Braun and Clarke (2006: 92) argue that this identification is related to 'what is of interest about them and why.' The researchers utilised a conceptual perspective to empirical findings through comparing different data sets and interpreting plausible relationships and variations in the patterns. Comparing the Greek case studies data sets involved two tiers of analysis. In the first tier, codes were categorized across different methods' data sets. The second tier consists of clusters of codes which have been recognized as meaningful in both schools. This coding enabled comparisons of the complexities, interactions and level of differentiation in two case-study schools.

\section{Findings and Discussion}

School A is a medium-sized comprehensive school (391 students) in a suburb of Athens with high socioeconomic status, led by a headteacher who has been in post for a year, while school B is a model/pilot Music school, with 439 students, led by a headteacher $(\mathrm{AB})$ who has been in post for 15 years. These case study schools are the two best state schools in one district in the prefecture of Attiki, based on secondary school students' results in the Panhellenic exams, for two consecutive years (20082010).

Given that 'outstanding leadership is exquisitely sensitive to the context in which it is exercised' (Leithwood et al., 1999: 4), contextual factors, such as school status (e.g. the experimental/pilot type of school B allow greater discretion in the teaching and learning process; years of headship experience; and, principals' readiness to create 
unofficial mechanisms to maintain a strong focus on teaching and learning, created a platform for variation in leadership for learning practices in the Greek context.

\section{$\underline{\text { Vision for Learning }}$}

Vision is among the most important leadership practices that successful leaders include in their repertoire. Earley et al. (2002) and Bush (2008) agreed with Leithwood et al.'s (2006: 34) finding that successful school leadership includes the notion of vision as the practice of enhancing 'motivation and inspiration for the work of staff' as an important dimension for the organisation's future.

Within the Greek context, vision is not a widely discussed concept, and this may be related to the absence of a formal vision, which is striking in government policy documents. The school A principal pinpoints the government's focus on targets rather than vision:

the government does not want us to think outside the box and beyond its directives, as to my understanding, politicians expect us to be target-translators and not strategic vision builder.

This confirms other participants' view of a complete lack of vision, which would have ensured a sense of school direction. A consequence of a centralized government educational policy is the expectation of passive implementation by the school, without having any participation in its formulation. There is no distinctive school vision and, perhaps as a consequence, teachers are not given an opportunity to participate in vision building. This contrasts with the concept of a common vision with shared ownership, as shown in a Norwegian context (Møller, 2009). The finding that both principals attempted to be 'bureaucratically' correct, by including government goals within school targets, confirms Konidari and Abernot's (2006) research in Greek secondary schools, which shows a lack of shared vision between 
the educational partners, and lack of communication from the base to the top of the hierarchical pyramid.

However, the cross-case analysis of the Greek high-performing schools shows both principals attempting to adopt a visionary role. The school context affects stakeholders' involvement in vision formation. The different approaches are related to the lack of an official vision statement, the limitations of leadership in improving the quality of learning at school level, as well as leaders' different practices to reconcile the demands of the centralized system with the school context. The overwhelming emphasis on a results-driven approach leaves little room for teaching innovation in school A, but there is more room for experimentation in a model school (school B). The lack of vision at the two case study schools confirms Bagakis's (2007a: 164) point that

[t]he [Greek] schools usually do not have targets to meet and they do not have substantial pedagogical discussions. It is often evident that the 'letter of the law' is [the main] schools' ... priority ... The culture of the 'automatic pilot' and the lack of vision and orientation of each school [is evident in the Greek context].

Whilst the development of personalised student learning in both schools might be considered as a de facto vision to enhance learning, variations in implementation were observed. This partly reflects the impact of the national financial limitations on a costly policy to manage students' learning beyond the normal school timetable. School B shows greater scope for personalization due to teachers' flexibility to focus on students' learning within a model school. In contrast, school A's approach is limited to individual teachers' initiatives to develop personalised 'out of class' learning intervention targeted lessons. At school A's teachers' meeting, the principal stressed the value of enhancing students' achievement through extra curricula activities (i.e. Physical Sciences experiment competition involvement) and all 
teachers agreed to a Physics teacher's comment that 'we set a vision to get the very best of each child by providing them with opportunities beyond lessons'.

Surprisingly, a personalised nature of learning can be considered as an 'extra-mile' approach within state schools, as they are known for their obsolete practices, as evidence shows:

Government schools are not expected to use innovative teaching methods but basic pedagogy -sometimes reminding us our own school days, our teachers' teaching- to make sure the material is delivered. (School A deputy head)

Participants in both schools agreed on a vision which strives to make students enjoy their learning within a school system which does not create a stimulating learning and teaching environment, due to the limitations of an exam-oriented framework. This may explain the narrow emphasis on a vision, which does not allow space for developing transferrable skills and 'a complete $21^{\text {st }}$ century citizen' (Greek language and literature teacher) while limiting the scope for developing a wider approach to education, as modules such as citizenship, drama, and skills development, are marginalized. This notion contrasts with Norway, where an enthusiastic and enjoyable approach to learning remains at the heart of its vision (Møller, 2009).

\section{Curriculum Management}

Centralization is a significant feature of curriculum design, planning and organisation in Greece. Curriculum management is centrally directed by the Ministry of Education and the Pedagogical Institute (PI) ${ }^{1}$ while schools have limited scope to shape curriculum decision-making. The findings shed light on principals' indirect

\footnotetext{
${ }^{1}$ With the Law 3966/ 2011, the Pedagogical Institute (PI) has been abolished while the Institute of Educational Policy (IEP) established to operate as an executive scientific body which supports the Ministry of Education, Lifelong Learning and Religious Affairs, through its scientific research and studies on primary and secondary education issues. The authors retain this name as the Greek research participants used the PI acronym.
} 
involvement in pedagogic-leadership activities due to the principal's limited knowledge of various subjects. Within both Greek schools, the principals and deputy heads' roles are constrained by the burden of managerial tasks while they mainly adopt 'curriculum processor' roles, based on the PI structured specifications in the core national examination subjects. Despite the official conceptualization of principals as curriculum leaders, the central government restricts senior leaders' ability to align the curriculum to specific school needs. Similar to Saliaris's (2009) study, both principals' role is bounded as government policy implementator, rather than as a curriculum leader guiding intervention in curriculum design. Secondary school principals' central focus on the national examination procedure limits the flexibility to offer more creative and collaborative patterns in curriculum.

However, both principals have taken the role of curriculum reviewers and coordinators to provide a supportive culture for pedagogical tasks. A Greek language and literature teacher illustrates the general view about how school B's headteacher oversees teaching and learning:

Our principal constantly assures the quality of teaching and learning activities by ensuring that nobody deviates from a learning-centred lesson. When needed, he helps us to activate practices that affect students' learning, either through giving his consent to modify aspects of the curriculum, unofficially, or through creating the space to make us help students individually.

Similarly, school A's principal contended that:

I'm open to curriculum modifications -even though some practices are forbidden within state schools-... as long as they contribute to our students' progress.

Externally, the role of the subject advisers is mainly strategic, deciding 'the what and how' of curriculum implementation in accordance with the Pedagogical Institute's (PI) guidelines, for example through organising pedagogical seminars to maximize teachers' effectiveness. However, even in cases of under-performance, the subject 
advisers' pedagogical involvement is constrained by law because 'the law does not allow me to enter classes' (Maths adviser). This was confirmed by school leaders and teachers, leading one teacher (school B Maths teacher) to say that subject advisers have 'disappeared'.

The teacher's role is primarily one of execution with very limited influence on curriculum:

In the pan-hellenic exam modules, teachers cannot do anything else but teach what we are given to teach. Teaching final year students is like teaching a parrot to speak. (School B Maths experienced teacher)

This finding is consistent with international studies, such as Printy (2008) and Webb et al. (2004), where the curriculum is mainly driven by central governmental requirements. Curriculum modifications are not acceptable, as 'the PI monitors that we follow Grade C teaching syllabus, by the book, as students are examined at a national level in the PI's national curriculum.'(School A Greek teacher) In practice, however, teachers may make limited unofficial deviations from the highly structured curriculum 'with the tacit agreement of the head' (school A principal), 'in order to make it more appropriate for the demanding nature of the exams.' (school B deputy head) In the same vein, Demertzi and Bagakis's (2006: 144) Greek study showed that 'there is some collaboration among the staff concerning teaching design' but a limited room 'for stretching the national curriculum framework.'

\section{$\underline{\text { Evaluation of student results }}$}

Evaluating students' results is the responsibility of teachers whereas the senior members of Greek schools are entitled to participate only in the assessment of class performance at the termly pedagogical meetings of the schoolteachers' council. 
Individual students' tracking of progress is not widely discussed between the principal and the teachers, although there is a formal expectation from senior school members for teachers to monitor student progress. Subject advisers are not systematically involved in advising teachers about enhancing individual student progress, due to teachers' reluctance to have a pedagogical dialogue, in terms of overcoming barriers to students learning, as well as subject advisers' invisibility in schools.

International studies highlight the indirect impact of leaders' on student outcomes in high performing schools (e.g. Heck, 2000; Murphy et al., 2007; Ofsted, 2009; Macfarlane and Woods, 2011), but this was not perceived as a strong relationship in Athens because of the principals' lack of systematic and robust reviewing of students' results. In contrast to school A, where there is limited engagement with monitoring student academic progress, school B has introduced year group meetings, class meetings, subject teachers' meetings and teachers' dialogue about strategies for improving academic development.

The lack of formal school strategies for additional academic support is linked to the absence of after-school supportive tutorials, provided by the Ministry of Education (until 2009), due to the financial cuts from the central authority. Despite this problem, both principals have encouraged teachers to invest in 'additional individualised support of the examination of core modules' (School B Greek language teacher). This occurs during their administrative allocated time and it has been perceived as a 'secret' common practice in state schools (e.g. take the student out of the PE, English or RE classes to have an extra session with a teacher of a core module). This was evidenced at school A principal's shadowing day, where a Maths 
teacher informed the principal about a temporary curriculum change with the purpose of offering his Grade C students extra tuition in mathematics.

\section{Monitoring teachers' performance}

Principals' monitoring of the teaching and learning process is seen as surveillance by teachers in Greece while attempts at evaluation by the school subject advisers is hampered by resistance from the teachers' trade union. The majority of participants agree with school A's Maths teacher that 'unfortunately the Teachers' Union considers teacher's evaluation as a threat and not as a means of improving our teaching.' The Maths school adviser (FC) adds that observing classroom teaching in order 'to evaluate teachers' performance would have given rise to a storm of protest and there would be a general outcry from OLME's ${ }^{2}$ side.'

Participants' perceptions about their Teacher Union's negative attitude to evaluation confirms earlier Greek literature (e.g. Papakonstantinou, 1993; Athanasoula-Reppa, 2008; Christodoulou, 2007; Saliaris, 2009) which shows that there is no trust in the people who are in the position to monitor teachers' performance due to a lack of training, leading to concerns about the evaluators competence (skills and subject knowledge). Previous research refers to this as the most 'authoritarian model of inspectorship' (Katsikas and Kavvadias, 1998: 107) and a threat (Mavrogiorgos, 2003) with possible dismissal, in case of under-performance.

Formal evaluation is enacted by the subject advisers and principals, only in case of serious complaints about a teacher's pedagogical ineffectiveness. The researched principals agreed that they can only discreetly oversee teaching and learning, as:

2 OLME: Greek Federation of State School Teachers of Secondary Education 
neither the principal nor the subject advisers can get into the class and stand there as

a scarecrow for students so that the teacher can work better. (School A deputy head)

Leithwood et al.'s (2008: 32) overview of successful school leadership showed that 'a key task for leadership, if it is to influence pupil learning and achievement, is to improve staff performance.' In addition, Robinson et al. (2008: 662) pinpointed that 'the degree of leader involvement in classroom observation and subsequent feedback was $[\ldots]$ associated with higher performing schools' and these observations helped teachers to improve their teaching. However, observation is not perceived as a mechanism for improvement and heads in these two Greek researched schools have limited authority, as school A's principal confirms:

Since the subject adviser or I had to get a permission of the teacher in order to be able to observe a series of his/her lessons, the system has failed for me, that's my view. The teacher has refused to give me access in her class and it seems that $\mathrm{s} / \mathrm{he}$ did not want me to find out whether and why s/he has shown an unacceptable performance and attitude in class. It is a shame, though, that neither the subject expert nor me had the actual right to change this reality.

\section{Mentoring and Coaching}

Within a centralized education system, there are no discernible differences between the two Greek schools. The data suggest that there is no official mentoring or coaching for teachers. However, there are elements of informal mentoring for newly qualified teachers, for example by school B's deputy head. In contrast, external subject advisers have a formal mentoring role for subject teachers but, in practice, they are rarely able to exercise it. This connects to Simkins et al.'s (2006: 332) comment, in respect of coaching for English middle leaders, that 'it looks like a paper exercise'.

An informal culture of instructional improvement has been developed by all subject teachers in both schools. Sharing ideas and practices is embraced by most school A 
teachers through professional dialogues which occur informally in the staff room, during break times and at the Greek philologist team meetings. However, the Biology teacher's point that:

in Greece, we think that nobody in our field knows better than we do. There are teachers who think that they are the Kings in their Kingdom, and as a consequence they rarely discuss about their teaching with their peers.

Peer coaching is more evident in school B, where it is an informal strategy implemented by teachers to improve their teaching practices and set a professional learning culture orientation. This suggests that teachers' advanced subject knowledge does not leave space for the principals to intervene in their pedagogical role. Notably, in the Leadership for Learning project, one of the Greek gymnasium schools created a culture of 'sharing good practice amongst colleagues [as it] was seen as an important means to achieve [...] improvement.' (Dempster and Bagakis, 2009: 93) However, in contrast to Biniari's (2012) research finding that there is no collaborative culture of reflection leading to teachers' learning in an Athens school, the current study consolidates the idea of informal professional dialogues linked to a trusting collegial relationship in the case study schools.

A pattern of coaching that the Greek subject advisers are officially expected to implement is 'technical coaching' (Garmston, 1987) through transferring new teaching skills and strategies to teachers. Such coaching

fits excellently into an educational system which is becoming ever more inclined to bureaucratic forms of control over its employees in order to secure the implementation of centrally-determined, standardized forms of "effective" instruction (Darling-Hammond, 1985; NcNeil, 1986). (Hargreaves and Dawe, 1990: 234)

\section{Modelling}


Greek subject advisers are expected to develop a collaborative community with the purpose of fostering consistency of subject teaching practice, through modelling teaching practices. However, teachers are often unwilling to attend sessions organized by the subject advisers. The Maths subject adviser's explanation is related to teachers' mentality 'to do their job and then go home', whereas teachers complain about the nature of these modeling sessions (not up-to-date material, unrealistic pedagogical teaching methods, non-interesting topics covered). School leaders do not engage in modeling, largely because of their limited engagement with teaching. School B's principal convincingly argues that:

since my time is $99 \%$ devoted to managerial issues, whereas one hour per week I do teaching, I wouldn't value my teaching as outstanding to show to my colleagues because I am high in the managerial hierarchy.

This evidence reinforces a widely accepted notion that Greek principals mainly focus on management, not on teaching and learning, and this does not enable them to model good practice.

Whilst both Greek schools have acknowledged the merits of taking initiatives to create a platform for peer-sharing of effective teaching, aspects of reciprocal learning within their subjects is practiced by only a small number of teachers. This limited peer modeling is explained by the Maths adviser's argument that 'Greek teachers are not accustomed to open-door practices through which they improve their teaching skills, foster their subject knowledge and enhance their pedagogical management of the class'. The limited nature of this practice may be the outcome of an organisational system which does not support collaborative approaches.

Undoubtedly, creating a climate for strengthening professional growth through modelling teaching has been difficult, due to 'the Greek mentality that no one teaches 
better than me', as school A's principal argues. Similarly, a fear of colleagues' criticisms was reported to be hindering this practice in Biniari's (2012) study. In model school $\mathrm{B}$, however, modelling is a widely exercised practice within and across schools in the same educational prefecture. This takes the form of 'sharing effective pedagogical practices' within a friendly boundary framework where 'only the school colleagues who are well-disposed towards us, participate. But it is only few of us who regularly create learning spaces within the school', as a Maths teacher admits. Also, in contrast to Pashiardis and Savvides' (2011) research in Cyprus, where model lessons have been designed for the weak teachers, model school $\mathrm{B}$ is open to the professional learning community of the district, without any sense of this being performance-driven.

\section{Continuing Professional Development (CPD)}

The notion of CPD has been perceived by OECD (2001) as a vital notion in promoting teachers' growth within and beyond teaching. Teachers' professional development in Greece has been mainly provided through conventional pathways such as the Ministry-sponsored training seminars- run by subject advisers, the Pedagogical Institute/ Institute of Educational Policy, the Prefectural Training Centre (PEK), the Hellenic Mathematics Society, and the Laboratory Centre for Physical Sciences (EKFE). Case study participants criticised the ineffective nature of these programmes because they are perceived to be out of date, following outmoded teaching practices, or because of inappropriate times and venues, a view which confirms the findings of Vitsilaki-Soroniati (2002) and Konidari and Abernot (2006) in Greece, and OECD's (2009) study in European countries. Similarly, Frost's (2012: 216) comment that 'dissatisfaction with outmoded forms of CPD [is] reflected in low 
numbers of teachers attending professional development events' is echoed in the Greek case studies.

The value of in-school training for the professional improvement of teachers was stressed in school B. However, the strategy of sharing good practice, materials and ideas has been a matter of debate within school A, despite the recognition of its benefits to improving the quality of teaching and in ensuring consistency in lessons. This confirms Vitsilaki-Soroniati's (2002: 43) view that 'teachers have not experienced alternative training programmes such as in-house, collaborative professional development programmes within their own schools, [as] teachers do not believe that these trends could be implemented in the Greek school context [...].' In contrast, the majority of school B participants highlighted the provision of unofficial in-house professional development, mainly through creating a 'subject targeted community for learning', as stated by the deputy head. Biniari's (2012) research showed that practices enhancing teachers' learning within their schools are not put in place. However, the present research demonstrates that some participants have a drive to change the public's perceptions about Greek state school education. This finding is also highlighted by School A experienced Greek language teacher:

Those of us who treat teaching as a profession and not as a civil servant task -like an 8 a.m. to 2 p.m. job- truly work very hard to prove the society wrong about views on teacher's status and government schools' role.

As evidenced mainly in school B (its status is untypical), those teachers with curriculum time flexibility look beyond the status quo and develop proactive mechanisms to influence their professional learning.

\section{Conclusion}


Although leadership is influenced by the context where it is exercised, it is not constrained totally by centralisation, as there were elements of informal instructional leadership. As Table 1 depicts, there is a limited school-based IL adopted by official leaders, while the role is conceived as an external role. This external control is partly via the subject advisers but, in practice, this is not fully enacted, and disparaged by school teachers and leaders. As a consequence, this leaves space for informal schoollevel instructional leadership exercised by teachers, since principal instructional leadership is deemed to be of secondary importance in a bureaucratically driven school reality.

\section{Table 1: To be inserted here}

\section{$\underline{\text { Answering the research questions }}$}

Whether, and to what extent, Greek principals are instructional leaders?

Principal's instructional leadership is not given a high priority in Greece due to system policy and school expectations for principals to act as government administrative servants with 'top-down' implementing skills. The constraints of the hierarchy, and the highly administrative orientation of Greek principalship (Biniari, 2012; Saliaris, 2009; Christodoulou, 2007; Saitis, 2005; Stravakou, 2003) prevent principals from devoting a lot of time to pedagogical activities. School A principal's pedagogical involvement is related to the creation of a culture of instructional improvement, with a vision for learning and curriculum management to boost students' performance. The instructional leadership practices of school B principal highlight a leading strategic-instructional role through a clear vision, allocation of curriculum subjects, monitoring students' progress, along with a non-leading 
pedagogical role which enhances teachers' encouragement for peer-coaching, modelling within and across the schools in the district, and ensuring CPD provision, with the purpose of enhancing the quality of teaching and learning.

The recognition that IL is not confined to the principals creates space for a sense of shared leadership in the two researched schools, while its implementation is inevitably linked to system constraints. As Bush (2014: 3) argues,

given the recognition that leadership is about influence, not formal authority, instructional leadership could emanate from many different sources and be seen as one aspect of a distributed approach.

Both Greek HPSS cases provide evidence of an unofficial instructional 'teacher leadership' (Frost, 2012) culture, which shows the potential for reconsidering leadership in Greek state schools. Filling the pedagogical gap created by the ineffectiveness of subject advisers' role, and the outmoded nature of $\mathrm{CPD}$, seems to lead to construction of informal reflective learning cultures, mainly within subject expertise networks. Also, most subject teachers' active involvement in curriculum unofficial modifications and provision of extra instructional support to students, adds to their instructional leadership role. Teachers established informal shared leadership practices to ensure that pedagogical initiatives are put in place to support the development of the 'lost purpose of Greek state schools, which must be the school as the main tool for student achievements', as noted by a Maths teacher in school A.

If so, how do they act as instructional leaders?

This research evidence confirms that leadership execution varies markedly by context, while the similarities arise from implementing government policy. This also 
raises questions about the boundaries of, and opportunities for, leadership enactment in centralised systems. Both Greek principals were able to introduce IL initiatives, under the umbrella of curriculum timetable changes, to maximize final year students' learning. Unlike school A's principal, whose role is more utilitarian, predominantly as the managerial official of the system, school B's principal had more discretion to enact informal instructional leadership behaviours, to support teachers' instructional development, which indirectly influenced student learning. The experimental-model nature of school B created a platform for the principal to have an active involvement in curriculum modifications, supporting unofficial intervention lessons with elements of student learning personalization, and encouraging model teaching across the schools in the same district.

Within the centralised Greek context, an informal horizontal and limited IL pattern may be the outcome of a tightly prescribed organizational system and a consequence of insufficient enactment by positional leaders.

\section{Significance}

Given the significance of leadership in enhancing learning, this study contributes to generating new knowledge on instructional leadership through its contribution to IL in centralized systems. The literature shows that relatively little is known about IL in centralised and bureaucratic contexts because it is largely focused on Western countries. The constraints on principals' instructional leadership, arising from their predominant administrative role, revealed the emergence of a nexus of IL relationships, which do not depend on hierarchical norms. 
The study demonstrates theoretical significance in its focus on the collaborative and reciprocal nature of instructional leadership. The knowledge base for IL captured in this study extends international understanding of distributed or shared instructional leadership (Marks and Printy, 2003; Lee et al., 2012). Despite the hierarchical limitations, the pedagogical empowerment of the Greek teachers creates a participative instructional leadership culture. This relates not only to curriculum ownership, featured in other European literature (e.g. Norris et al. (1996) for Finland and Boyd-Barrett and O’Malley (1995) for Spain) but also links to other instructional leadership activities (e.g. monitoring student progress, mentoring and coaching), which are not necessarily related to the school hierarchy or centralised imperatives.

A growing focus on learning instead of teaching is the second aspect of theoretical significance, despite the IL name suggesting a focus on 'instruction [which] predisposes people to think in terms of teaching rather than learning [...].' (MacBeath, 2006: 39) This signifies a shift to a learning paradigm, in which the introduction of the 'participative teachers' instructional leadership' concept contradicts the established perceptions of a paucity of leadership within the Greek system.

\section{References}

Athanasoula-Reppa, A. (2008) 'Teaching evaluation of educators in Greece', in P. Pashiardis, I. Savvides and A. Tsiakiros (eds), Evaluation of Educators' Teaching: From Theory to Practice, Athens Greece: Ellin Publications, 39-60 (in Greek).

Athanasoula-Reppa, A. and A. Lazaridou (2008) 'Requirements, roles, and challenges of the principalship in Greece and Cyprus: newly appointed principals' views', European Education, 40(3): 65-88.

Bagakis, G. (2007a) 'Schools' support within the Carpe Vitam programme. Leadership for Learning: $2^{\text {nd }}$ Low secondary school of Petroupolis', in G. Bagakis, K. Demertzi and T. Stamatis (eds), A School Learns: Development 
and School Self-evaluation within the Carpe Vitam: Leadership for Learning Project, Athens Greece: Livanis Publications, 151-165 (in Greek).

Bagakis, G. (2007b) 'Reviewing the Greek educational changes after the Carpe Vitam participation. Leadership for Learning' in G. Bagakis, K. Demertzi and T. Stamatis (eds), A School Learns: Development and School Self-evaluation within the Carpe Vitam: Leadership for Learning Project, Athens Greece: Livanis Publications, 263-273 (in Greek).

Biniari, L. (2012) The Development of School Self-evaluation Tools for Leadership for Learning. A Portrait and Profile, PhD thesis, Greece: The University of Patras (in Greek).

Blase, J. and Blase, J. (2004) Handbook of Instructional Leadership: How Successful Principals Promote Teaching and Learning, 2nd edn., Thousand Oaks, CA: Corwin Press.

Bossert, S. T., Dwyer, D. C., Rowan, B. and Lee, G. V. (1982) 'The instructional management role of the principal', Educational Administration Quarterly, 18(3): 34-64.

Boyatzis, R.E. (1998) Transforming qualitative information: thematic analysis and code development, Thousand Oaks, CA: SAGE.

Boyd-Barrett, O. and O'Malley, P. (1995) Education reform in democratic Spain, London: Routledge.

Braun, V. and Clarke, V. (2006) 'Using thematic analysis in psychology', Qualitative Research in Psychology, 3(2): 77-101.

Brundrett, M. and Rhodes, C. (2014) Researching Educational Leadership and Management, London: SAGE Publications Ltd.

Bryman, A. (2008) Social Research Methods, New York: Oxford University Press.

Bush, T. (2007) 'Authenticity in research - reliability, validity and triangulation', in A. Briggs and M. Coleman (eds), Research Methods in Educational Leadership and Management, 2nd edn., London: Sage, 91-105.

Bush, T. (2008) 'From management to leadership: semantic or meaningful change?', Educational Management Administration \& Leadership, 36(2): 271-288.

Bush, T. (2014) 'Instructional leadership in centralised contexts: rhetoric or reality?', Educational Management Administration \& Leadership, 42(1): 3-5.

Bush, T. and Glover, D. (2009) 'Managing teaching and learning: a concept paper', Johannesburg: Matthew Goniwe School of Leadership and Governance (MGSLG). Available at:

http://www.mgslg.co.za/Download-document/Managing-teaching-andlearning-A-concept-paper-Tony-Bush-Derek-Glover-2009.html

Accessed on December $10^{\text {th }}, 2009$

Bush, T., Joubert, R., Kiggundu, E. and Van Rooyen, J. (2010) 'Managing teaching and learning in South African Schools', International Journal of Educational Development, 30(2): 162-168.

Christodoulou, A. (2007) School management from the principal's perspective: selfconception of the principal's role, MA dissertation, Greece: University of Thessaloniki (in Greek).

Cohen, L., Manion, L. and Morrison, K. (2001) Research Methods in Education, London: RoutledgeFalmer.

Coldren, A. F. and Spillane, J. P. (2007) 'Making connections to teaching practice: the role of boundary practices in instructional leadership', Educational Policy, 21(2): 369-396. 
Cortazzi, M. (2002) 'Analysing narratives and documents', in M. Coleman and A.R.J. Briggs (eds), Research Methods in Educational Leadership and Management, London: SAGE, 196-212.

Creswell, J. W. (2003) Research Design: Qualitative, Quantitative, and Mixed Methods Approaches, London: Sage.

Crossley, M. and Vulliamy, G. (1984) 'Case-study research methods and comparative education', Comparative Education, 20(2): 193-207.

Darling-Hammond, L. (1985) 'A proposal for evaluation in the teaching profession', The Elementary School Journal, 86: 530-553.

Day, C., Harris, A. and Hadfield, M. (2001) 'Challenging the orthodoxy of effective school leadership', International Journal of Leadership in Education, 4 (1): 39-56.

Day, C., Sammons, P., Hopkins, D., Harris, A., Leithwood, K., Qing, G., Penlington, C., Melta, P., and Kington, A. (2007) The Impact of School Leadership on Pupil Outcomes: Interim Report, Research Report DCSF-RR018, Nottingham: University of Nottingham.

Demertzi, K. and Bagakis, G. (2006) 'Exploring the educators' perceptions for leadership and learning in one Greek low secondary school', in G. Bagakis (ed.), Educational Changes, the Educator's and School Contribution, Athens Greece: Metaixmio, 135-145 (in Greek).

Demertzi, V., Bagakis, G. and Georgiadou, S. (2009) 'School voices in leadership for learning within the Greek context', International Journal of Leadership in Education, 12(3): 297-309.

Dempster, N. and Bagakis, G. (2009) 'Leadership and learning: making the connections', in J. MacBeath and N. Dempster (eds), Connecting Leadership and Learning: Principles for Practice, London: Routledge, 91-105.

Earley, P., Evans, J., Collarbone, P., Gold, A. and Halpin, D. (2002) Establishing the Current State of School Leadership in England, London: Institute of Education, University of London (Research Report No 336). Available at: http://www.education.gov.uk/publications/eOrderingDownload/RR336.pdf Accessed on April 10 $0^{\text {th }}, 2010$.

Educational Law 1566/85 Structure and Operation of Primary and Secondary Education, Paper 167/ 30-9-1985 Hellenic Republic (online) (in Greek). Available at: http://www.mech.ntua.gr/gr/selections/law/files_law/N_1566_1985.pdf Accessed on November 15th, 2009.

Educational Law 1304/82 Scientific- Pedagogical Guidance and Management in General Education and Technical- Vocational Education, Paper 144/ 7-121982 Hellenic Republic (online) (in Greek). Available at:

http://www.fa3.gr/nomothesia_2/nomoth_education/5_kathik_symvouloi-n1304-1982.htm

Accessed on November 15th, 2009.

Educational Law 2525/97 Comprehensive Upper Secondary School, Entrance of Student Candidates in Tertiary Education; The Evaluation of The Educational Professional Work, FEK 188/ 23-9-1997 Hellenic Republic (online) (in Greek). Available at:

http://edu.klimaka.gr/nomothesia/fek/1419-education-ekpaidevtikinomothesia-nomoi-fek.html

Accessed on November 15th, 2009.

Educational Law 3966/2011 Policy Framework for the Model Experimental Schools; The Establishment of the Institute of Educational Policy; Organisation of the 
Institute of Computers Technology and Publishing 'Diofantos, FEK 118/2011 Hellenic Republic (online) (in Greek). Available at:

http://edu.klimaka.gr/nomothesia/fek/1322-fek-118-2011-peiramatika-sxoleiadiofantos-n3966.html

Accessed on November 15th, 2011.

European Union (2009) Council Conclusions of 26 November 2009 on the professional development of teachers and school leaders, (Official Journal 2009/C 302/04, 12.12.2009).

Fitzgerald, T. (2007) 'Documents and documentary analysis: reading between the lines', in A. Briggs and M. Coleman (eds), Research Methods in Educational Leadership and Management, 2nd edn., London: Sage, 278-294.

Frost, D. (2012) 'From professional development to system change: teacher leadership and innovation', Professional Development in Education, 38(2): 205-227.

Garmston, R. J. (1987) 'How administrators support peer coaching', Educational Leadership, 44(1): 18-26.

Gkolia, C. and Brundrett, M. (2008) 'Educational leadership development in Greece', in M. Brundrett and M. Crawford (eds), Developing School Leaders: An International Perspective, London: Routledge, 41-57.

Gray, D. E. (2005) Doing Research in the Real World, London: Sage.

Gumus, S. and Akcaoglu, M. (2013) 'Instructional leadership in Turkish primary schools: an analysis of teachers' perceptions and current policy', Educational Management Administration \& Leadership, 41(3): 289-302.

Hallinger, P. (2009) Leadership for 21st Century School: From Instructional Leadership to Leadership for Learning, Hong Kong: The Hong Kong Institute of Education (online). Available at:

http://www.ied.edu.hk/cplectures/include/getfile.php?file=1267581769.pdf\&fi lepath=resource\&filename=Hallinger\%20-\%20Booklet\%20-\%20Final.pdf Accessed on December 10 ${ }^{\text {th }}, 2011$.

Hallinger, P. (2010) 'Developing instructional leadership', in B. Davies and M. Brundrett (eds), Developing Successful Leadership, London: Springer, 61- 76.

Hallinger, P. and Heck, R. H. (1997) 'Exploring the principal's contribution to school effectiveness', School Effectiveness and School Improvement, 8(4): 1-35.

Hallinger, P. and Heck, R. H. (2011) 'Exploring the journey of school improvement: classifying and analyzing patterns of change in school improvement processes and learning outcomes', School Effectiveness and School Improvement, 22(1): $1-27$.

Hallinger, P. and Lee, M. (2014) 'Mapping instructional leadership in Thailand: Has education reform impacted principal practice?', Educational Management Administration \& Leadership, 42(1): 6-29.

Hallinger, P. and Murphy, J. (1985) 'Assessing the instructional management behavior of principals', The Elementary School Journal, 86(2): 217-247.

Hargreaves, A. and Dawe, R. (1990) 'Paths of professional development: contrived collegiality, collaborative culture, and the case of peer coaching', Teaching \& Teacher Education, 6(3): 227-241.

Heck, R. H. (2000) 'Examining the impact of school quality on school outcomes and improvement: A value-added approach', Educational Administration Quarterly, 36(4): 513-552. 
Heck, R. H., Larsen, T. J. and Marcoulides, G. A. (1990) 'Instructional leadership and school achievement: Validation of a causal model', Educational Administration Quarterly, 26(2): 94-125.

Katsikas, C. and Kavvadias, G.K. (1998) School Crisis and Educational Policy. A Critique of the Educational Changes, Athens Greece: Gutenberg (in Greek).

Khan, S. and VanWynsberghe, R. (2008) 'Cultivating the under-mined: Cross-Case Analysis as Knowledge Mobilization', Forum: Qualitative Social Research, 9(1).

Konidari, V. and Abernot, Y. (2006) 'From TQM to learning organisation: another way for quality management in educational institutions', International Journal of Quality \& Reliability Management, 23(1): 8-26.

Krug, S. E. (1992) 'Instructional leadership: a constructivist perspective', Educational Administration Quarterly, 28(3): 430-443.

Lai, E. and Cheung D. (2013) 'Implementing a new senior secondary curriculum in Hong Kong: instructional leadership practices and qualities of school principals', School Leadership and Management, 33(4): 322-353.

Leadership Improvement for Student Achievement (LISA) (2009) The Leadership Cocktail: A Highly Contextual Mix, Project funded by the Education, Audiovisual \& Culture Executive Agency of the EU, The Netherlands.

Lee, M., Hallinger, P. and Walker, A. (2012) 'A distributed perspective on instructional leadership in International Baccalaureate (IB) schools', Educational Administration Quarterly, 48(4): 664-698.

Leithwood, K., Day, C., Sammons, P., Harris, A. and Hopkins, D. (2006) Seven Strong Claims about Successful School Leadership, Nottingham: National College for School Leadership (NCSL) (online). Available at: http://www.aede-france.org/Seven-strong-claims.html Accessed on October $28^{\text {th }}, 2009$.

Leithwood, K., Harris, A. and Hopkins, D. (2008) 'Seven strong claims about successful school leadership', School Leadership \& Management, 28(1): 2742.

Leithwood, K. and Jantzi, D. (2008) 'Linking leadership to student learning: the contributions of leader efficacy', Educational Administration Quarterly, 44(4): 496-528.

Leithwood, K., Jantzi, D. and Steinbach, R. (1999) Changing Leadership for Changing Times, Buckingham: Open University Press.

MacBeath, J. (2006) 'A story of change: growing leadership for learning', Journal of Educational Change, 7(1): 33-46.

MacBeath, J. and Dempster, N. (2009) Connecting Leadership and Learning: Principles for Practice, London: Routledge.

MacBeath, J. and Swaffield, S. (2008) 'Leadership for learning: a matter of principle', paper presented at the 21st International Congress for School Effectiveness and Improvement, The Leadership for Learning (Carpe Vitam) Project: The Legacy, Auckland, New Zealand, 6th-9th January 2008.

MacBeath, J. and Townsend, T. (2011) 'Leadership and learning: paradox, paradigms and principles', in T. Townsend and J. MacBeath (eds), International Handbook of Leadership for Learning, London: Springer International Handbooks of Education, 1-25.

Macfarlane, R. and Woods, D. (2011) Glimpses of Greatness, London: London Leadership Strategy supported by the National College for Leadership of Schools and Children's Services. 
Marks, H. M. and Printy, S. M. (2003) 'Principal leadership and school performance: an integration of transformational and instructional leadership', Educational Administration Quarterly, 39(3): 370-397.

Mattar, D. (2012) 'Instructional leadership in Lebanese public schools', Educational Management Administration \& Leadership, 40(4): 509-531.

Mavrogiorgos, G. (2003) 'Why there is much "discussion" about the educators' evaluation', Educators Club, 30, 26-27 (in Greek).

Ministerial Decision 353.1/324/105657/A1/2002 (FEK 1340B/16-10-2002) Specifications of the Directors of the Regional Bureaus for primary and secondary education, headteachers and deputy heads of schools and SEK and school teachers' association responsibilities (online) (in Greek). Available at: http://edu.klimaka.gr/nomothesia/fek/1309-fek-1340-2002-kathikontaarmodiotites-stelechoi-ekpaideysis.html Accessed on November 15th, 2011.

Møller, J. (2009) 'Learning to share: a vision of leadership practice', International Journal of Leadership in Education, 12(3): 253-267.

Muijs, D. (2011) 'Researching leadership: towards a new paradigm', in T. Townsend and J. MacBeath (eds), International Handbook of Leadership for Learning, London: Springer International Handbooks of Education, 115-125.

Murphy, J., Elliot, S. N., Goldring, E. and Porter, A. C. (2007) 'Leadership in learning: a research-based model and taxonomy of behaviours', School Leadership and Management, 27(2): 179-201.

NcNeil, L. (1986) Contradictions of Control: School Structure and School Knowledge, New York: Methuen/Routledge \& Kegan Paul.

Normand, R. (2014) Between civil service and republican ethics: the statist vision of leadership among French principals (online). Available at:

https://www.idmarch.org/document/National+College+for+School+Leadership/ nsEeshow/Between+civil+service+and+republican+ethics\%3A+the+statist+vis ion+of+leadership+among+French+principals+Romuald+Normand\%2C+Prof essor+Research+Unit+SAGE+\%28Societies \%2C+Actors+and+Government+o f+Europe $\% 29+$ Faculty+of+Social+Sciences $\% 2 \mathrm{C}$ Accessed on June $15^{\text {th }}, 2014$.

Norris, N., Aapland, R., Macdonald, B., Schostak, J and Zamorski, B. (1996) An independent evaluation of comprehensive curriculum reform in Finland, Helsinki: National Board of Education.

Office for Standards in Education (Ofsted) (2009) Twelve Outstanding Secondary Schools: Excelling Against the Odds, London: The Office for Standards in Education, Children's Services and Skills.

Organisation for Economic Co-operation and Development (OECD) (2001) New School Management Approaches, Paris: OECD.

Organisation for Economic Co-operation and Development (OECD) (2009) Creating Effective Teaching and Learning Environments: First Results from TALIS (online). Available at: http://www.oecd.org/edu/school/43023606.pdf Accessed on November $25^{\text {th }}, 2010$.

Pansiri, N. O. (2008) 'Instructional leadership for quality learning: an assessment of the impact of the primary school management development project in Botswana', Educational Management Administration \& Leadership, 36(4): 471-494. 
Papakonstantinou, P. (1993) Educating and School Evaluation, Athens Greece: Ekfrasi (in Greek).

Papanaoum, Z. (1995) School Management: Theoretical Analysis and Empirical Research, Thessaloniki: Kyriakides (in Greek).

Pashiardis, P. and Savvides, V. (2011) 'The interplay between instructional and entrepreneurial leadership styles in Cyprus rural primary schools', Leadership and Policy in School, 10(4): 412-427.

Perakyla, A. (2008) 'Analyzing talk and text' in N. K. Denzin and Y. S. Lincoln (eds), Collecting and Interpreting Qualitative Materials, London: Sage, 351374.

Printy, S. M. (2008) 'Leadership for teacher learning: a community of practice perspective', Educational Administration Quarterly, 44(2): 187-226.

Robinson, V. M. J., Lloyd, C. A. and Rowe, K. J. (2008) 'The impact of leadership on student outcomes: an analysis of the different effects of leadership types', Educational Administration Quarterly, 44(5): 635-674.

Robson, C. (2002) Real World Research: A Resource for Social Scientists and Practitioner-Researchers, Oxford: Blackwell.

Rui, Y. (2007) 'Comparing policies', in M. Bray, A. Bob and M. Mason (eds), Comparative Education Research: Approaches and Methods, Comparative Education Research Centre, The University of Hong Kong: Springer.

Sahlberg, P. (2007) 'Education policies for raising student learning: the Finnish approach', Journal of Education Policy, 22(2): 147-171.

Saiti, A. (2000) Education and Economic Development, Athens: Tipothito, Giorgos Dardanos (in Greek).

Saitis, C. (2002) The Principal of the Contemporary School: from Theory to Practice, Athens Greece: Self-publication (in Greek).

Saitis, C. (2005) Organisation and Management of School Units, Athens: Selfpublication (in Greek).

Saitis, C. and Eliophotou- Menon, M. (2004) 'Views of future and current teachers on the effectiveness of primary school leadership: evidence from Greece', Leadership and Policy in Schools, 3(2): 135-157.

Saitis, C., Fegkari, M. and Voulgaris, D. (1997) 'Redefining the role of leadership in the modern school', Dioikitiki Enimerosi, 7: 87- 108 (in Greek).

Saliaris, D. (2009) Principal's Role in the Curriculum Implementation and Evaluation Process in Secondary Education in the Islands of Chios and Rhodes, MA dissertation, Rhodes Greece: The University of the Aegean (in Greek).

Silverman, D. (2005) Doing Qualitative Research: A Practical Handbook, 2nd edn., London: Sage.

Simkins, T., Coldwell, M., Caillau, I., Finlayson, H. and Morgan, A. (2006) 'Coaching as an in-school leadership development strategy: experiences from leading from the middle', Journal of In-Service Education, 32(3): 321-340.

Southworth, G. (2002) 'Instructional leadership in schools: reflections and empirical evidence', School Leadership \& Management, 22(1): 73-91.

Stake, R.E. (2006) Multiple Case Study Analysis, New York: The Guilford Press.

Stravakou, P. (2003) The School Principal in Primary and Secondary Education: Theoretical Analysis and Empirical Research, Thessaloniki: Kyriakides (in Greek).

Swaffield, S. and MacBeath, J. (2009) Researching leadership for learning across international and methodological boundaries, Annual Meeting of the 
American Educational Research Association. San Diego (online). Available at: http://www.educ.cam.ac.uk/centres/lfl/about/swaffieldmacbeath\%20aera09.pdf Accessed on December 20 2009.

Vitsilaki-Soroniati, C. (2002) 'Life long learning of educators: a case study in the programme "upgrading the primary school educators" , Epistimes Agogis, 2: 37- 60 (in Greek).

Webb, R., Vulliamy, G., Hämäläinen, S., Sarja, A., Kimonen, E. and Nevalainen, R. (2004) 'A comparative analysis of primary teacher professionalism in England and Finland', Comparative Education, 40(1): 83-107.

Yin, R. K. (2009) Case Study Research: Design and Methods, 4th edn., London: Sage. 
TABLE 1

\begin{tabular}{|c|c|c|}
\hline IL Dimensions & Similarities & Differences \\
\hline $\begin{array}{l}\text { Vision for } \\
\text { Learning }\end{array}$ & $\begin{array}{l}\text { - Absence of a formal vision } \\
\text { - Stakeholders' restricted } \\
\text { visionary role: } \\
\text { oResults-driven vision } \\
\text { oA focus on enjoying learning }\end{array}$ & $\begin{array}{l}\text {-Vision implementation } \\
\text {-Personalization of learning }\end{array}$ \\
\hline $\begin{array}{l}\text { Curriculum } \\
\text { Management }\end{array}$ & $\begin{array}{l}\text { - Centralised management of } \\
\text { teaching and learning } \\
\text { - School leaders acting as } \\
\text { 'curriculum processors' and } \\
\text { reviewers (modifications are } \\
\text { encouraged to enhance student } \\
\text { learning) } \\
\text { - Constrained strategic subject } \\
\text { advisers' role } \\
\text { - Teachers: unofficial deviations } \\
\text { on curriculum }\end{array}$ & $\begin{array}{l}\text { There are no discernible differences } \\
\text { between the two Greek schools and } \\
\text { this is attributed to centralization. }\end{array}$ \\
\hline $\begin{array}{l}\text { Evaluation of } \\
\text { students results }\end{array}$ & $\begin{array}{l}\text { - Periodic students' evaluation } \\
\text { - School's unofficial supportive } \\
\text { mechanism for improving } \\
\text { students' learning } \\
\text { - Principal A' lack of systematic } \\
\text { reviewing of results } \\
\text { - Subject advisers: limited } \\
\text { advisory role }\end{array}$ & $\begin{array}{l}\text { - A series of discussion meetings on } \\
\text { monitoring results (School B) } \\
\text { - Informal personalization of } \\
\text { intervention in the pan-hellenic } \\
\text { modules (School B) }\end{array}$ \\
\hline $\begin{array}{l}\text { Monitoring } \\
\text { teachers' } \\
\text { performance }\end{array}$ & $\begin{array}{l}\text { - Inactive implementation } \\
\text { of the law } \\
\text { - Principals' informal } \\
\text { evaluation of teachers' } \\
\text { performance } \\
\text { - Subject advisers' limited } \\
\text { authority, due to teachers' } \\
\text { unwillingness } \\
\end{array}$ & $\begin{array}{l}\text { Based on the data presented in this } \\
\text { paper, there are no discernible } \\
\text { differences between the two Greek } \\
\text { schools. }\end{array}$ \\
\hline $\begin{array}{l}\text { Mentoring } \\
\text { and } \\
\text { Coaching }\end{array}$ & $\begin{array}{l}\text { - Senior leaders' role: } \\
\text { head's mentoring } \\
\text { qualified teachers; subject } \\
\text { advisers' limited role) } \\
\text { - Teachers' peer professional } \\
\text { discussions }\end{array}$ & - Peer coaching (school B) \\
\hline Modelling & $\begin{array}{l}\text { - Limited modelling of subject } \\
\text { advisers } \\
\text { - Principal's invisible role in } \\
\text { modelling due to their } \\
\text { managerial focus of their role } \\
\text { - Limited peer-sharing of } \\
\text { effective teaching in their } \\
\text { subject-knowledge domain }\end{array}$ & $\begin{array}{l}\text { - The extent of teachers' modelling } \\
\text { and teacher leadership: In School } \\
\text { B, modelling is a widely exercised } \\
\text { practice within and across schools, } \\
\text { mainly due to its status (Model } \\
\text { school). }\end{array}$ \\
\hline $\begin{array}{l}\text { Continuing } \\
\text { Professional } \\
\text { Development } \\
\quad(\mathrm{CPD})\end{array}$ & - Official central provision & $\begin{array}{l}\text { - In-house professional } \\
\text { development through teachers' } \\
\text { communities for learning } \\
\text { (school B) }\end{array}$ \\
\hline
\end{tabular}

Table 1: Summary of similarities and differences between two Greek high-performing schools 